\title{
ŚREDNIOWIECZNE MALOWIDŁO NA WSCHODNIEJ ŚCIANIE PREZBITERIUM KOŚCIOŁA ŚW. JAKUBA W TORUNIU. TRANSMEDIALNA STRUKTURA OBRAZOWA?
}

\section{Streszczenie}

Niedawne prace konserwatorskie w prezbiterium kościoła św. Jakuba w Toruniu ujawniły kilka szczegółów wcześniej słabo czytelnego malowidła z trzeciej ćwierci XIV wieku. Owe szczegóły rzuciły ciekawe światło na jego ikonografię i na złożony charakter medialny. Po obejrzeniu z bliska świeżo oczyszczonego, wysoko na ścianie wschodniej prezbiterium umieszczonego przedstawienia aniołów adorujących (i podtrzymujących) dotąd trudny do określenia czworoboczny kształt zwieńczony szczycikiem, określany domyślnie jako Weraikon, okazało się, że najprawdopodobniej znajdował się tu wstawiony niegdyś w czworoboczne pole niewielki obraz tablicowy. Świadczą o tym: kilkucentymetrowa „odsadzka” wykonana w tynku - umiejscowiona w dolnej części namalowanego czarnym konturem architektonicznego, baldachimowego obramienia, brak śladów tynku (jedynie nietypowa, cienka warstwa czerwonej polichromii wewnątrz obramienia). Ze względu na to, że ów domniemany obraz się nie zachował, przypuszczenie, że przedstawiał Weraikon, ujęty architektonicznym cyborium, być może naśladującym rzymski sposób prezentacji chusty-relikwii, opieramy na popularności przedstawień tego typu ikonograficznego, umiejscawianych w kontekście ołtarza i na podstawie istniejącego kontekstu malarskiego (na sklepieniu w bezpośrednim sąsiedztwie znajdują się także wizerunki adorujących aniołów z inskrypcją tersanctus).

* Anna Błażejewska - dr hab. historii sztuki, prof. UMK, Katedra Historii Sztuki i Kultury, Uniwersytet Mikołaja Kopernika w Toruniu; e-mail: abl@umk.pl

https://orcid.org/0000-0003-2786-897X

** Elżbieta Pilecka - dr hab. historii sztuki, emerytowana prof. UMK; Uniwersytet Mikołaja Kopernika w Toruniu; e-mail: drpilecka@wp.pl

https://orcid.org/0000-0002-8144-7116 
Przy ogromnej popularności tego typu przedstawienia w późnym średniowieczu, nie tylko $\mathrm{w}$ malarstwie monumentalnym, toruński przykład wydaje się wyjątkowy z racji swojej transmedialności: całość jest heterogeniczna; kopia obrazu-relikwii występuje w nowym kontekście i roli, zmieniając także charakter malowidła. Źródłem takiej koncepcji była zapewne niezwykła różnorodność (w tym także medialna) tworzonych kopii wizerunku rzymskiego. Podobieństwo do tego typu złożonej medialnie struktury obrazowej możemy odnaleźć w księgach iluminowanych, do których bywały wklejane wizerunki Świętego Oblicza wykonane na skórze, niekiedy przywiezione z Rzymu. Toruński wizerunek mógł mieć także rzymskie pochodzenie; wiek XIV był okresem znacznego wzmożenia kultu Świętego Oblicza w samym Rzymie, jak i poza nim, choćby dzięki licznym pielgrzymkom.

Należy przy tym zastrzec, że funkcjonowanie tu wstawionego, malowanego na desce Weraikonu jest jedynie hipotezą, choć uznajemy ją za wielce prawdopodobną. Istnieje też i inna, mniej prawdopodobna możliwość, że wspomniana odsadzka/półka powstała bez związku z malowidłem. Wówczas możliwe byłoby, iż przedmiotem adoracji jest umieszczona pod baldachimem Arka Przymierza lub jedynie miejsce „oczekujące” na Arkę, która ukaże się w ,świątyni Boga” w dniu Sądu (Ap 11,19).

Słowa kluczowe: kościół św. Jakuba; Weraikon; Święte Oblicze; Toruń; średniowiecze

„Pod samym sklepieniem jest obraz, który jednak uległ wielkiemu zniszczeniu, że nie można było określić, kogo przedstawia"

(,Słowo Pomorskie”, 8 IX 1936)

To lakoniczne prasowe stwierdzenie przez wiele lat było w zasadzie jedyną wzmianką o niewielkim malowidle ściennym odkrytym podczas prac renowacyjnych prowadzonych w latach 1934-1936 w prezbiterium kościoła pw. św. Jakuba w Toruniu ${ }^{1}$. Szerzej pisano wówczas o znacznie lepiej zachowanej, bogatej, figuralnej i ornamentalnej dekoracji malarskiej, jaka uwidoczniła się na sklepieniu chóru po zdjęciu tynków pokrywających wnętrze od czasów użytkowania kościo-

${ }^{1}$ Prace mające na celu odnowienie prezbiterium zainicjowano jesienią roku 1933 pod kierunkiem konserwatora poznańsko-pomorskiego Witolda Dalbora, przy czym prace przy sklepieniu podjęto na przełomie listopada i grudnia 1934 roku. Miały na celu głównie zdjęcie warstw tynku ze ścian i sklepień. Bezpośrednie kierownictwo nad pracami sprawował inż. arch. Zygmunt Knothe. Zob. Cenne odkrycia w presbiterjum kościoła św. Jakóba w Toruniu, „Słowo Pomorskie”, nr 267 (19 XI 1933), s. 12. Wrócono do nich po krótkiej przerwie w 1935 roku, jak donoszono: Odkrycie średniowiecznych malowidet ściennych $w$ kościele św. Jakóba, „Słowo Pomorskie”, nr 12 (15 I 1935), s. 6. Znalazła się tu wzmianka o malowidłach przedstawiających aniołów na sklepieniu o dekoracyjnych wzorach podkreślających podziały żebrowe i inskrypcjach w ościeżach okien. Brak informacji o malowidle na ścianie wschodniej mógł wynikać z jego ścisłego tematycznego i kompozycyjnego powiązania z malowidłami na sklepieniu; dowodem bowiem na ich równoczesne odsłonięcie jest zdjęcie zamieszczone w: Odsłonięto cenny zabytek średniowiecza, „Słowo Pomorskie”, nr 208 (8.09.1936), s. 8, jak i zdjęcie zamieszczone na wklejce w: W. Dalbor, Średniowieczne malowidła w kościele św. Jakuba w Toruniu, „Teka Pomorska”, R. 1-2, (1936-37) nr 3-4, s. 8-11. 
ła przez protestantów (w latach 1557-1667). Choć w pierwszej nocie prasowej z roku $1935^{2}$ donoszono jedynie o ,malowidłach na sklepieniu”, mamy prawo przypuszczać, że pod tym sformułowaniem kryło się także, powiązane z nimi stylowo i tematycznie, owo niepozorne, wciśnięte między łuk sklepienia a ostrołuk okna, niemal nieczytelne malowidło na wschodniej ścianie prezbiterium.

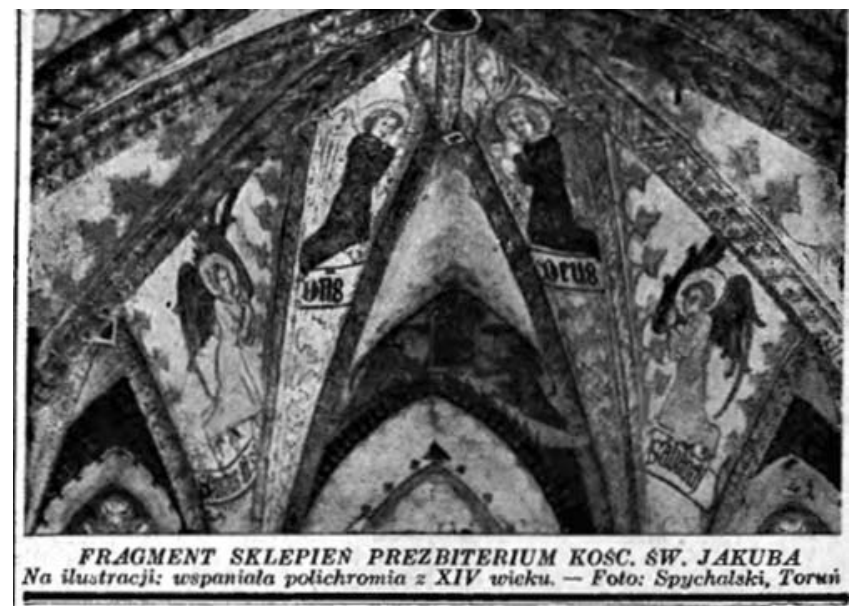

Il.1. Malowidła na sklepieniu i ścianie wschodniej prezbiterium kościoła św. Jakuba w Toruniu. Stan bezpośrednio po odsłonięciu ich w latach 30. XX wieku.

(Źródło: „Słowo Pomorskie”, 8.09.1936, s. 8).

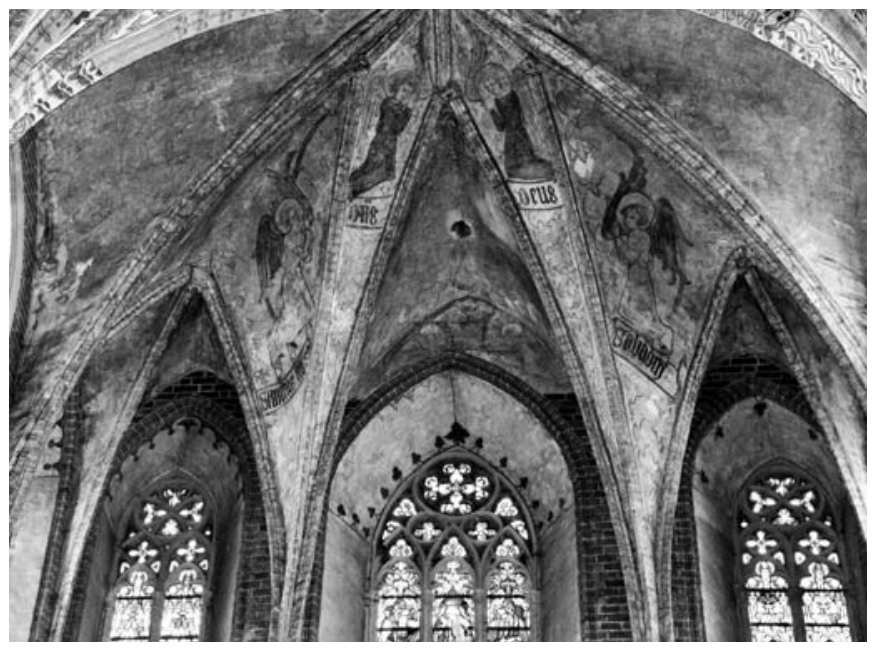

Il.2. Malowidła na sklepieniu i ścianie wschodniej prezbiterium kościoła św. Jakuba w Toruniu. Stan z roku 2014 - sprzed ostatniej konserwacji.

(fot. A. Błażejewska)

\footnotetext{
${ }^{2}$ Por. Odkrycie średniowiecznych malowidet.
} 
Zarówno cztery anioły ukazane na sklepieniu z towarzyszącą im inskrypcją z aklamacji mszalnej: Sanctus Scs'S Dns Deus Sabaoth [Sanctus, Sanctus, Sanctus Dominus Deus Sabaoth] $]^{3}$, jak i dwa wyobrażone w strefie sklepienia na wschodniej ścianie chóru namalowano w przyklęku, w akcie modlitewnej adoracji. Wyobrażenia te, tekst inskrypcji oraz kontekst malowideł - ołtarz główny - nie pozostawiają wątpliwości, iż utworzony przez nie obrazowy przekaz miał odnosić się bezpośrednio do sprawowanej przy ołtarzu ofiary eucharystycznej. Jednakże przedmiot adoracji, ujmowany przez dwa anioły wyobrażone na ścianie wschodniej, prezentował się nader enigmatycznie; jako trudno czytelny czworoboczny kształt, o zarysach uchwytnych jedynie dzięki wysuniętym ku niemu i dotykającym go dłoniom aniołów, a nie ze względu na to, co przedstawiał.

Literatura na temat tytułowego malowidła prezentuje się - jak dotąd - bardzo skromnie. Poza wspomnianą krótką wzmianką prasową z 1936 roku$^{4}$, donoszącą o jego nieczytelności, z innych wypowiedzi tego czasu możemy wnioskować o malowidle jedynie pośrednio. I tak: figuralną dekorację malarską sklepienia prezbiterium uznano za powstałą pod wpływem niemiecko-flandryjskich inspiracji artystycznych ${ }^{5}$, a ze względu na „formę aniołów” datowano ją na trzecią ćwierć XIV wieku'. Konserwator Witold Dalbor, wysoko oceniając walory estetyczne całej dekoracji sklepienia, anioły określił jako cherubiny w akcie modlitwy, wykonane przez artystę wywodzącego się z francuskiego środowiska artystycznego ${ }^{7}$. Właściwie dopiero Maria Michnowska ${ }^{8}$ wzmiankowała malowidło na wschodniej

\footnotetext{
${ }^{3}$ Inskrypcja zaczerpnięta z tekstu proroka Izajasza (Iz 6,3): „W roku śmierci króla Ozjasza ujrzałem Pana siedzącego na wysokim wyniosłym tronie, a tren jego szaty wypełniał świątynię. Serafiny stały ponad Nim: każdy z nich miał po sześć skrzydeł: dwoma zakrywał swą twarz, dwoma okrywał swoje nogi, a dwoma latał. I wołał jeden do drugiego: „Święty, Święty, Święty jest Pan Zastępów. Cała ziemia pełna jest Jego chwały”. Pismo Święte Starego i Nowego Testamentu, Poznań 1980, s. 853-854.

${ }^{4}$ Por. Odstonięto cenny zabytek.

${ }^{5}$ Tamże.

${ }^{6}$ Por. Odkrycie średniowiecznych malowidet.

${ }^{7}$ Dalbor, Średniowieczne malowidta, s. 8-9. Czas powstania określił jako krótko po połowie XIV wieku; zob. też: Z. Knothe, Kościót św. Jakuba, w: Kościót i parafia świętego Jakuba w Toruniu. Z okazji 25-letniego jubileuszu kapłaństwa Ks. L. Kozłowskiego, dodatek do: „Wiadomości Kościelnych”, Toruń 1938, s. 19-33, s. 31-32; krótka wzmianka o malowidłach na sklepieniu także u: G. Chmarzyński, Sztuka pomorska, w: Słownik Geograficzny Państwa Polskiego i Ziem historycznie z Polska zwiazanych, red. S. Arnold, t. 1, z. 4: Pomorze Polskie, Pomorze Zachodnie, Prusy Wschodnie, Warszawa 1937, szp. 377; G. Brutzer, Mittelalterliche Malerei im Ordenslande Preussen, Teil 1: Westpreussen, Danzig 1936, s. 39.

${ }^{8}$ M. Michnowska, Malowidła ścienne z XIV w. w kościele św. Jakuba w Toruniu, „Teka Komisji Historii Sztuki”, 3, Prace Wydziału Filologiczno-Filozoficznego, Towarzystwo Naukowe w Toruniu, t. 15, red. J. Puciata-Pawłowska, Toruń 1965, s. 15-16, 56. Badaczka stwierdza, że temat ów harmonizuje z rodzajem wnętrza, w którym się znajduje, choć jego charakter jest „uniwersalny”. Niestety, malowidło to nie zostało wspomniane w obszernej dokumentacji sporządzonej przez M. Michnowską na zlecenie Pracowni Konserwacji Zabytków: Malowidła ścienne w kościele św. Jakuba w Toruniu, dokumentacja historyczna, oprac. M. Michnowska, mps, Toruń 1962, Archiwum Kujawsko-Pomorskiego Urzędu Ochrony Zabytków w Toruniu, sygn. 208.
} 
ścianie prezbiterium $\mathrm{w}$ ramach szerszego omówienia średniowiecznej dekoracji malarskiej kościoła św. Jakuba, starając się określić jego temat i sens. Uznała je za „adorację Świętego Oblicza przez anioły głoszące tersanctus”, gdzie anioły „sławią Zbawiciela jako człowieka i drugą osobę boską" ". Jako analogię dla umieszczenia Weraikonu nad ołtarzem podała przykład bardziej rozbudowanego ujęcia tematu w katedrze w Moguncji (ok. 1370 rok) ${ }^{10}$. Od tego czasu pojawiło się zaledwie kilka wzmianek, w tym dwie autorstwa Jerzego Domasłowskiego w syntezach: malarstwa ściennego w Polsce ${ }^{11}$, gdzie autor także określił wyobrażenie jako Weraikon (i jednocześnie jako piątą fazę malowideł w tym kościele, datowaną na ok. 1390 rok) i malarstwa gotyckiego w Polsce, gdzie nazwę Weraikon przytoczył już ze znakiem zapytania ${ }^{12}$. W kontekście Weraikonu jako motywu ikonograficznego w późnośredniowiecznej sztuce Torunia kilka uwag poświęciła malowidłu Halina Turska ${ }^{13}$. Pomiędzy aniołami dostrzegła trzymaną przez nie chustę z niewidocznym (jak uznała) wskutek zniszczeń wizerunkiem twarzy Chrystusa. Eucharystyczne odniesienie wizerunku - zwłaszcza ze względu na jego ołtarzowy kontekst - sprecyzowała jako unaocznienie dogmatu o transsubstancjacji, w którym anioły były aniołami Mszy św., a twarz Chrystusa na chuście symbolizowała, czy wręcz utożsamiała hostię spoczywającą na korporale.

Brak informacji o prowadzeniu jakichkolwiek prac przy tych malowidłach w okresie powojennym ${ }^{14}$ - aż do niedawno ukończonej kompleksowej restauracji

\footnotetext{
${ }^{9}$ Michnowska, Malowidla ścienne, s. 16, 56.

${ }^{10}$ Tamże, s. 15-16, zastrzegając, że znane są też i inne tego typu przedstawienia.

${ }^{11}$ J. Domasłowski, Polska pótnocno-wschodnia, t. 3, w: Materiaty do katalogu gotyckich malowidet ściennych $w$ Polsce, red. A. Karłowska-Kamzowa, Poznań 1981, s. 57.

${ }^{12}$ J. Domasłowski, Kościót parafialny Nowego Miasta p.w. św. Jakuba, w: Malarstwo gotyckie w Polsce, t. 2: Katalog zabytków, red. A.S. Labuda, K. Secomska, Warszawa 2004, s. 101-102 powtarza swoje wcześniejsze datowanie i określenie tematu; podobnie: L. Krantz-Domasłowska, J. Domasłowski, Wyposażenie wnętrz, w: Kościót św. Jakuba w Toruniu, seria: „Zabytki Polski Północnej”, nr 11, Toruń 2001, s. 72.

${ }^{13}$ H. Turska, Veraicon $w$ średniowiecznym Toruniu, „Acta Universitatis Nicolai Copernici”, seria: „Zabytkoznawstwo i Konserwatorstwo”, 44 (2013) s. 58, 62-64. H. Turska powtarza datowanie malowideł za J. Domasłowskim - ok. 1390 roku. Jako analogie do toruńskiego przedstawienia (typ, lokalizacja) podaje przykład malowidła w kościele śś. Piotra i Pawła w Hosinie, a w regionie jako wcześniejsze realizacje tego tematu wymienia przykłady iluminatorstwa książkowego, zwracając uwagę, że wyobrażenia te pojawiały się w kontekście tekstów liturgii mszalnej.

${ }^{14}$ Dokumentacja z prac konserwatorskich 1956-59: kościół św. Jakuba - konserwacja malowideł ściennych 1956-59, mps, Toruń 1959, Archiwum Kujawsko-Pomorskiego Urzędu Ochrony Zabytków Toruń, sygn. 205 - dotyczy wyłącznie zachodniej części kościoła. O konserwacji w latach 50. i początku lat 60 . XX wieku pisał R. Żankowski, ale z tekstu można wnioskować, że chodzi o te przeprowadzone w części pod wieżą kościoła: R. Żankowski, Gotyckie malowidła ścienne w kościele św. Jakuba w Toruniu, odkryte i odrestaurowane w połowie XX wieku. Uwagi konserwatora o ich historii i ponownej, niedawnej konserwacji, w: Dzieje skarby kościoła świetojakubskiego w Toruniu. Materiały IV Sesji Naukowej SHS O/Toruń, red. K. Kluczwajd, seria: „Dzieje i skarby kościołów toruńskich”, Toruń 2010, s. 175.
} 
w latach 2014-2016 ${ }^{15}$, pozwala przypuszczać, że od lat 30. XX wieku do 2014 roku nie wykonywano żadnych prac ingerujących w substancję zabytku. Tym samym nasze badania i interpretacje odniosą się do uwidocznionej dopiero w ostatnich latach substancji zabytkowej.

Literatura przedmiotu określała przedstawienie jako scenę prezentacji Weraikonu, sugerując się jedynie kompozycją i gestem aniołów, bo w istocie nie były widoczne żadne malarskie cechy wizerunku Świętego Oblicza ${ }^{16}$. Taki sposób prezentacji - z udziałem aniołów - znany jest wprawdzie w średniowiecznej tradycji w odniesieniu do przynajmniej kilku typów ikonograficznych ${ }^{17}$, ale z racji popularności wizerunku Świętego Oblicza w późnym średniowieczu w różnych mediach obrazowych, jak i różnych kontekstach (w tym licznie w malarstwie ściennym we wnętrzach kościołów, zwłaszcza w kontekście ołtarza ${ }^{18}$ ) identyfikowanie tego przedstawienia $\mathrm{z}$ Weraikonem zdawało się nie budzić wśród dotychczasowych badaczy wątpliwości.

Możliwość oglądu malowidła z bliska, jak i sposobność dotknięcia powierzchni ściany bezpośrednio z rusztowań, ustawionych w trakcie ostatnich komplekso-

${ }^{15}$ Zob. Dokumentacja prac konserwatorsko-restauratorskich wnętrza prezbiterium i zakrystii kościoła św. Jakuba Apostoła w Toruniu - I etap, oprac. Irena i Jan Bulderberg, Włodzimierz Rumiński Relief s.c., Toruń 2014, kps, Archiwum Miejskiego Konserwatora Zabytków w Toruniu, sygn. 6679; Dokumentacja prac konserwatorsko-restauratorskich wnętrza prezbiterium i zakrystii kościoła św. Jakuba Apostoła w Toruniu - II i III etap, oraz prac konserwatorsko-restauratorskich ścian i łuku tęczowego, oprac. Irena i Jan Bulderberg, Włodzimierz Rumiński Relief s.c., Toruń 2016, kps, Archiwum Miejskiego Konserwatora Zabytków w Toruniu, sygn.7000.

${ }^{16}$ Niestety, nie wiadomo dokładnie, jak duża była ingerencja w substancję malowidła w trakcie prac restauratorskich w latach 30. XX wieku; w: Dokumentacja prac konserwatorskich, II i III etap, s. 5 - stwierdzono jedynie, że w drugiej, średniowiecznej fazie „,przemalowano też dwie pary aniołów adorujących Święte Oblicze”, przy czym nie wiadomo, czy nie chodzi tu o anioły na sklepieniu.

${ }^{17}$ Przede wszystkim był to typ ikonograficzny Chrystusa w Majestacie, np. w nadprożu SaintGénis-des-Fontaines w Katalonii (ok. 1020 rok), w Apokalipsie Beatusa z Saint Sever czy w kluniackich tympanonach: Thuret (Owernia), Dijon - Saint Bénigne, Moguncja, tympanon portalu zachodnim katedry i in. Anioły mogą też podtrzymywać konstrukcję otaczającą Arkę Przymierza, jak w rzeźbiarskiej dekoracji architektury - katedra Notre Dame w Paryżu (powyżej figury Madonny z Dzieciątkiem przedstawiono propitiatorium nad Arką Przymierza) czy w portalu katedry w Amiens. Należy też wspomnieć, że w tym czasie (po połowie XIV wieku) przyklękające, adorujące anioły towarzyszą Madonnie z Dzieciątkiem w przedstawieniach Madonn na Lwie, by wymienić tylko bardziej znane typy.

${ }^{18}$ Malowidła wyobrażające Weraikon trzymany przez anioły nierzadko znajdowały się w prezbiteriach, w bezpośrednim sąsiedztwie ołtarza. Poza wspomnianymi wcześniej przez badaczy przykładami można wymienić też malowidła z drugiej połowy XIV i XV stulecia: w dawnym kościele dominikanów w Bad-Wimpfen, w kaplicy zamkowej w Zwingenberg (Badenia Wirttembergia), w kościele mariackim w Heideck (Bawaria), w południowej krypcie kościoła St. Severin w Kolonii, w kościołach parafialnych w: Oedeheim, Schliengen (oba Badenia Wirttembergia), w Poniky (Słowacja) czy w małopolskim Czchowie. W najbliższym regionie - w podobnym kontekście - zachował się Weraikon w kościele parafialnym w Brodnicy, choć jest on umieszczony na ścianie nad łukiem tęczowym, więc jego związek z ołtarzem jest nieco luźniejszy. 
wych prac konserwatorskich prowadzonych przed kilku laty ${ }^{19}$, pozwoliły stwierdzić, na co właściwie patrzono od lat 30. ubiegłego stulecia, spoglądając z dołu ku wschodniej ścianie chóru, a w konsekwencji skłoniło do postawienia hipotez, co mogło stanowić centrum malowidła.

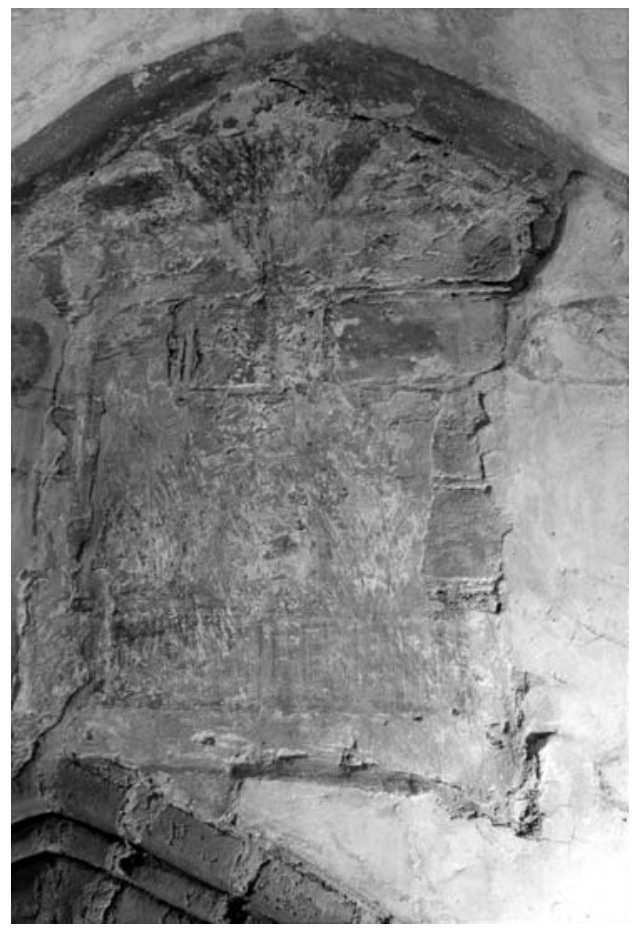

I1.3. Środkowa część malowidła na ścianie wschodniej prezbiterium kościoła św. Jakuba w Toruniu w 2014 roku, po oczyszczeniu powierzchni.

(fot. Rafał Jaguś)

Okazało się, że anioły gestem rąk i pozą prezentują coś, co ujęte było w namalowane czworoboczne obramienie, analogiczne do architektonicznego baldachimu, pod jakim na południowej ścianie chóru umieszczono wizerunek św. Filipa, jednego $\mathrm{z}$ dwóch patronów tego kościoła.

${ }^{19} \mathrm{~W}$ tym miejscu należą się serdeczne podziękowania firmie konserwatorskiej Relief, pracującej pod kierownictwem mgr Ireny Bulderberg, za możliwość obejrzenia malowidła w trakcie trwania prac. 


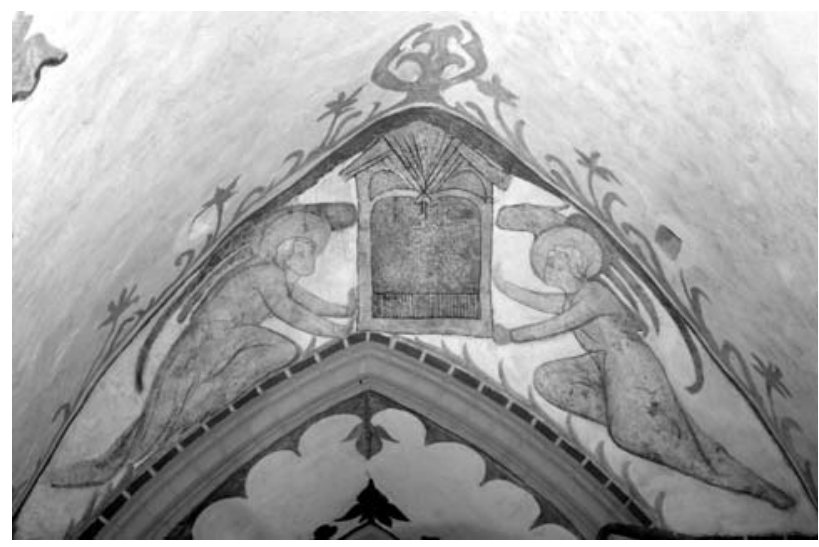

Il.4. Malowidło na ścianie wschodniej prezbiterium kościoła św. Jakuba w Toruniu w 2016 roku, po uzupełnieniach konserwatorskich. (fot. Rafał Jaguś)

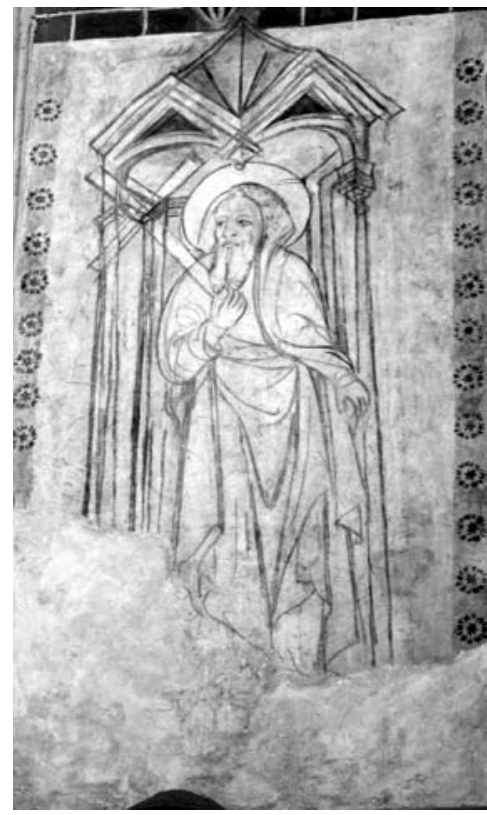

I1.5. Malowidło ścienne z przedstawieniem św. Filipa na ścianie pd. prezbiterium kościoła św. Jakuba w Toruniu. (fot. Anna Błażejewska) 
Stwierdzenie tej analogii pozwala przypuszczać, że dekorację malarską na ścianach chóru, w strefie sklepienia i na samym sklepieniu wykonał ten sam zespół, w tym samym czasie ${ }^{20}$ - sądząc po stylu lepiej zachowanych malowanych postaci patronów kościoła - po połowie XIV wieku, może w latach 60. lub ok. 1370 $\mathrm{roku}^{21}$. Kompozycja póz figur anielskich, układ i typ skrzydeł oraz zachowane linie modelunku szat zdają się wykazywać podobieństwa do czeskiego malarstwa trzeciej ćwierci XIV wieku ${ }^{22}$. Najistotniejsze jednak, że niewielka powierzchnia ściany w centrum całego przedstawienia pomiędzy wyobrażeniami aniołów (pokryta sporą warstwą kurzu), poza namalowaną architektoniczną niszą-baldachimem, tworzącą rodzaj obramienia $\mathrm{z}$ horyzontalnym pasem u dołu (zaznaczonym pionowymi równoległymi liniami), nie nosiła żadnych śladów malowidła! Co więcej, o ile anioły namalowano na tynku, podobnie jak boki i dół architektonicznej ramy-baldachimu, to górną część obramienia wykonano bezpośrednio na pierwotnej pobiale pokrywającej cienką warstwą ceglane lico. Pole wewnątrz obramienia pociągnięto - co wykazały analizy pobranych próbek - cieniutką warstwą pobiały, na którą nałożono bardzo cienką warstewkę czerwonego pigmentu ${ }^{23}$ (zob. il. 3,4). Najbardziej frapujący był jednak wyraźny poziomy występ, ok. $3 \mathrm{~cm}$ głębokości - rodzaj odsadzki wykonanej w grubości tynku w dolnej części prostokątnego pola. Uformowany został tak, że można było na nim coś osadzić. Owo „coś” zajmowałoby pole ujęte wspomnianą malowaną na tynku ramą architektoniczną, a u dołu zakrywałoby namalowany poziomy pas. Poza kilkoma niewielkimi, choć dość głębokimi otworkami brak jednak wyraźnych śladów mocowania czegokolwiek do ściany. Zatem jedynymi elementami, które możemy obecnie analizować, jest prezentowana przez anioły namalowana forma architektoniczna i wspomniana „odsadzka” w jej obrębie. Namalowaną strukturę architektoniczną przedstawiono jako baldachimową konstrukcję, zamkniętą od góry, wyrysowaną w perspektywicznym skrócie, przypominającą architektoniczne ażurowe zwieńczenia fial. W odróżnieniu od „poprawniejszej”, staranniejszej struktury baldachimu otaczającej wizerunek św. Filipa (zob. il. 5) ta wydaje się nieco

${ }^{20}$ Taką opinię wyraziła już M. Michnowska: Malowidła ścienne w kościele, s. 45. Postaci aniołów i malowany ornament na sklepieniu, jak też wizerunki apostołów na ścianach prezbiterium uznała za XIV-wieczne, negując opinię G. Brutzera o XV-wiecznej metryce postaci apostoła. Zob. Brutzer, Mittelalterliche Malerei, s. 39.

${ }^{21}$ Według badań dendrochronologicznych więźby nad prezbiterium drewno było ścięte w latach 1316-1317. Zob. A. Konieczny, Dzieje budowy kościoła św. Jakuba w Toruniu w XIV wieku w świetle analizy architektonicznej, „Biuletyn Historii Sztuki”, 74 (2012) nr 1, s. 11. Konieczny uważa, że prezbiterium zasklepiono ok. 1320 roku. Zasklepienie całego kościoła mogło też nastąpić dopiero po przekryciu dachem korpusu, którego więźba była założona nie wcześniej niż w 1361 roku. O więźbie dachowej nad nawą główną: Konieczny, Dzieje, s. 27. Domasłowscy datowali postaci patronów kościoła namalowane na ścianach prezbiterium na lata 80. XIV wieku. Domasłowska, Domasłowski, Kościót, s. 72.

${ }^{22}$ Zob. m.in. malowane postaci aniołów z krużganków klasztoru Emaus w Pradze, choć te są bardziej malarskie; toruńskie noszą cechy nieco starszego, bardziej linearnego stylu, także obecnego w Czechach.

${ }^{23}$ Zob. Dokumentacja prac konserwatorskich, II i III etap, s. 8. 
uproszczona ${ }^{24}$, w związku z czym jeszcze bardziej rzuca się w oczy bliżej nieokreślony poziomy pas wypełniający dolną strefę prostokąta, zakreślony gęstymi, rytmicznymi liniami pionowymi na całej swej długości. Zarówno detale w górnej partii tej „małej architektury”, jak i ów poziomy pas świadczą niezbicie, że dla twórców tego wizerunku była ona istotnym elementem całego przedstawienia.

Pojawiają się dwie możliwości wyjaśnienia znaczenia zaobserwowanychszczegółów:

albo „odsadzka” wykonana w tynku nie ma bezpośredniego związku z malowidłem, a namalowana baldachimowa struktura architektoniczna jest głównym motywem całego przedstawienia; na rzecz tej tezy przemawiałby fakt, że wsparty (ustawiony?) na poziomym uskoku przedmiot przesłoniłby dolną część malowanej architektury,

albo namalowana struktura architektoniczna miała na celu utworzenie iluzyjnej baldachimowej niszy-obramienia, w które wstawiono, wspierając na poziomej odsadzce, niewielki obraz na desce.

W pierwszym przypadku, gdyby przyjąć, że prezentowana przez anioły struktura architektoniczna to nie obramienie czegoś, co się nie zachowało, a wspominana ,odsadzka” w tynku nie ma związku z zamocowaniem czegokolwiek, można by wysunąć tezę, że wyobrażona architektura baldachimowa to przybytek-cyborium nad Arką Przymierza. Zrozumiała byłaby obecność aniołów - bądź jako integralnej części Arki Przymierza (,dwa też cheruby ze złota kute uczynisz po obu stronach wyrocznicy" - Wj 25,18), bądź jako asysta/straż wokół Przybytku²5. Za Arkę można by wówczas uznać wspomniany prostokątny, gęsto szrafowany pas w dolnej części architektonicznej struktury (zob. il. 4). Tu jednakże rodzi się pewne zastrzeżenie. Ów poziomy pas wizualnie bardziej odpowiada przedstawieniom stołu-ołtarza ${ }^{26}$, na którym stała Arka, niż samej Arki. Gęste, pionowe linie przypominają zarys antependium lub tkaninę rozpiętą wokół stołu, wyobrażaną na licznych przedstawieniach Arki Przymierza w średniowieczu ${ }^{27}$, chyba że Arka była przedstawiona jako niewielka pyxis.

${ }^{24}$ Niestety, nie wiemy, czy może została niedokładnie odtworzona w trakcie pierwszej konserwacji malowideł w latach 30. ubiegłego wieku. Uproszczenie czy też odmienność dotyczy zwłaszcza formy obramienia, która w przypadku naszego malowidła nie nosi cech architektonicznych podpór, przypominając prostą ramę obrazu.

${ }^{25}$ W liście wprowadzającym do 2 Księgi Machabejskiej (Mch 2,1-8) jest mowa o Arce Przymierza, ale bez cherubinów.

${ }^{26} \mathrm{Na}$ wzór biblijnego ,stołu z drzewa akacjowego” (Wj 25,23).

${ }^{27}$ Szereg przykładów zamieszcza: J. Nowiński, Ars eucharistica. Idee, miejsca i formy towarzyszace przechowywaniu eucharystii w sztuce wczesnochrześcijańskiej i średniowiecznej, Warszawa 2000, il. 38-41. Por. także ilustracje i podstawowe informacje o przedstawieniach Arki Przymierza w sztuce u: W. Neuß, Bundeslade, w: Reallexikon zur Deutschen Kunstgeschichte, Bd. 3 (1950), Sp. 112-118; w: RDK Labor, http://www.rdklabor.de/w/?oldid=89394 (dostęp: 11.08.2019); Bundeslade, w: Lexikon der christlichen Ikonographie, Hrsg. E. Kirschbaum u.a., Allgemeine Ikonographie, Bd 1, Rom 1968, Sp. 341-343. 


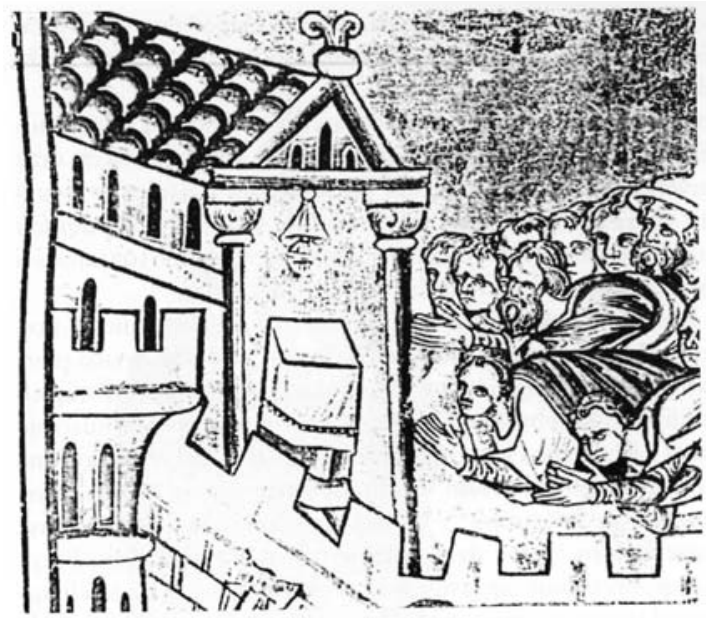

I1.6. Sancta Sanctorum w świątyni Salomona, fragment miniatury: Psatterz z Canterbury, ok. 1200.

(Źródło: J. Nowiński, Ars eucharistica, s. 150, il. nr 69)

Miejsce przechowywania Arki - przebłagalnia (propitiatorium) - w średniowieczu łączone było z miejscem przechowywania Eucharystii; od XIV wieku zyskało nowe nazwy: tabernaculum lub cyborium ${ }^{28}$. Można rozważyć jeszcze inną alternatywę, a mianowicie taką, że w toruńskim malowidle mielibyśmy do czynienia $\mathrm{z}$ wyobrażeniem, w którym celowo nie przedstawiono Arki, co mogłoby odpowiadać albo proroctwu Jeremiasza (Jr 3,16) ${ }^{29}$, albo słowom z Apokalipsy św. Jana, według których Arka Przymierza pojawi się dopiero w otwartych niebiosach na końcu czasów (Ap 11,19) ${ }^{30}$. Uznając jednak, że nieduże jest prawdopodobieństwo namalowania $\mathrm{w}$ obrębie niewielkiego czworobocznego pola jakiegoś przedmiotu, po którym nie zachowałby się żaden relikt, bardziej prawdopodobna staje się sugestia, że wyobrażono tu cyborium puste, oczekujące na Arkę, która objawi się w ,świecie przyszłym”. W prawdzie tradycja obrazowa - a znamy wiele przedstawień Arki w różnych wariantach i gatunkach artystycznych - przemawiałaby za przedstawieniem cyborium z Arką, to jednak pamiętajmy, że w średniowiecznej sztuce Prus pojawiały się tematy i ujęcia rzadkie lub wręcz unikatowe, więc i tej opcji nie można wykluczyć.

W drugim rozpatrywanym przez nas przypadku mielibyśmy z kolei do czynienia ze szczególną sytuacją badawczą, wynikającą z założenia, iż centralny (i za-

${ }^{28}$ Nowiński, Ars eucharistica, s. 104-107, 114.

${ }^{29}$, ,... nie będą więcej mówić: Skrzynia przymierza Pańskiego i nie przyjdzie im na myśl, ani nie będą jej wspominać ani nawiedzać, ani jej nie będzie więcej” (Jr 3,16; podkr. aut.). O teologicznych aspektach związanych z Arką Przymierza por. A. Mozgoł, Teologia Arki Przymierza w Ps. 132, Jr 3,14-18 oraz 2 Mch 2,1-8, „Śląskie Studia Historyczno-Teologiczne”, 33 (2000) s. 127-158.

${ }^{30}$ „I otworzony jest kościół Boży na niebie: i widziana jest skrzynia Testamentu jego w kościele jego". Biblia - to jest Ksiegi Starego i Nowego Testamentu, przełożone przez ks. J. Wujka (przedruk), Warszawa 1950, s. 277. 
razem główny) element struktury obrazowej to przedmiot dziś nieistniejący, po którym pozostały tylko ślady jego umiejscowienia, pozostałości czerwonego tła i malarski kontekst - obramowanie. Co mogłoby być „wpisane” w ów kontekst? Możemy zaledwie uchwycić domniemany czworoboczny obrys tego artefaktu, zajmujący wysokość niespełna trzech warstw cegieł, czyli - licząc wraz ze spoiną - ok. $30 \mathrm{~cm}$ (zob. il. 3). Jeśli w pustym dziś polu tkwiłby niegdyś wstawiony obraz, to $\mathrm{z}$ dużym prawdopodobieństwem można stwierdzić (zgodnie zresztą z intuicją kilku wcześniejszych badaczy), że był to Weraikon. Pamiętając o tym, że w tradycji obrazowania różne przedstawienia i motywy mogły być częścią składową sceny adoracji (i podtrzymywania) przez anioły ${ }^{31}$, należy zwrócić uwagę na fakt, iż nie wszystkie z nich niosły ze sobą medialną tradycję obrazu tablicowego. Tytułowe przedstawienie - Weraikon - o ile sformułowana wyżej hipoteza byłaby poprawna - byłby wizerunkiem włączonym w obraz w sposób dosłowny (realny) ${ }^{32}$, a nie obrazem wyobrażonym w/na obrazie ${ }^{33}$. Wówczas całość stanowiłaby wyobrażenie, które możemy określić jako transmedialne, zespalające malowidło ścienne i obraz tablicowy. Choć terminem transmedialność posługują się na ogół badacze sztuki współczesnej ${ }^{34}$, wydaje się, że Weraikon, mający transmedialność niejako w swojej naturze, sprawia wrażenie szczególnie predystynowanego do tego rodzaju złożonej medialnie prezentacji ${ }^{35}$. Autonomiczny wizerunek wstawiony w obrazscenę (jego) prezentacji przez anioły byłby (świadomym bądź nieświadomym)

${ }^{31}$ Poza wymienionymi w przyp. 18 niniejszego artykułu, także: Agnus Dei czy np. Chrystogram.

${ }^{32}$ Por. uwagi na ten temat: H. Belting, Obraz i kult. Historia obrazu przed epoka sztuki, Gdańsk 2010, s. 490; H. Bredekamp, Media obrazowe, „Artium Quaestiones”, 15 (2004) s. 213.

${ }^{33} \mathrm{~W}$ przypadku wyobrażeń Weraikonów - przedstawianie Świętego Oblicza jako obrazu w obrazie (mówi się tu o drugim stopniu medialności) należy wręcz do typowych ujęć tego tematu - od prezentowania chusty przez Św. Weronikę czy anioły, po obrazowanie go wśród Arma Christi. Być może ciekawe wyniki przyniosłyby badania statystyczne występowania różnych typów Weraikonu w określonych mediach. Wydaje się, że formuła z aniołami trzymającymi chustę/obraz z wizerunkiem Chrystusa była w malarstwie ściennym bardzo popularna.

${ }^{34}$ Transmedialność to pojęcie o nieostrej definicji; nierzadko uznawane za „właściwość” li tylko sztuki nowoczesnej i współczesnej. Zob. R.W. Kluszczyński (red.), Transmedializm. O twórczości Ryszarda Waśki, w: Obrazy na wolności. Studia z historii sztuk medialnych w Polsce, Warszawa 1998, s. 87-97; T. Załuski (red.), Transmedialność?, w: Sztuki w przestrzeni transmedialnej, Łódź 2010, s. 9-18 oraz w omówieniu tejże: W. Rubiś, Zagadnienia transmedialności w sztuce wspótczesnej. Wokót książki: Sztuki w przestrzeni transmedialnej pod redakcja Tomasza Załuskiego, „Estetyka i Krytyka”, 35 (2014) nr 4, s. 225: „niespotykana w sztuce dawnej transmedialność”. Szerszej rozumiana - jako idea przekraczania granic dziedzin sztuki, obecna już od antyku - zob. E. Wojtyniak-Dębińska, Transmedialność w grafice wspótczesnej, w: Sztuki w przestrzeni, s. 173.

${ }^{35}$ Leżący u podstaw obrazu-odbicia (odcisku) twarzy Chrystusa problem transmedialności, zawarty w legendach o samoistnym powielaniu się „cudownych” wizerunków w innych mediach (np. na szacie i na cegle - jak acheiropoietoi z Kamuliana i z Edessy), niewątpliwie otwierał drogę dla różnorakich transferów medialnych tego wizerunku.

Samo pojecie medium - z kilku przynajmniej względów - pojawia się w literaturze w kontekście Weraikonu: jako swoisty prawzór medium wizualnego. Por. Bredekamp, Media, s. 213-215. Zob. także o Weraikonie jako medium służącym zbawieniu: H. Schlie, Vera Icon in Medienverbund. Die Wirksamkeit der Sakramente und der Wirkung der Bilder, w: Medialität des Heils im späten Mittelalter, Hrsg. C. Dauven-van Knippenberg u.a., Zürich 2009, s. 65-70; J. Weitbret, The Vera 
podkreśleniem specyficznego statusu Weraikonu: umieszczonego w obrazie, ale jednocześnie przynależnego nie tylko do niego. Moc, jaką czerpie każda kopia Świętego Oblicza z oryginału-odbicia, sytuuje go w wielkiej grupie obrazówkopii o sile działania równej pierwotnemu Weraikonowi, a tym samym wiąże go ściśle $\mathrm{z}$ realnym obliczem Chrystusa ${ }^{36}$. W późnym średniowieczu Weraikon jako typ obrazowy był już znany przynajmniej w kilku wariantach, obecny w różnych mediach i w różnych kontekstach: w dekoracji malarskiej wnętrz sakralnych, w modlitewnikach i ołtarzykach do prywatnej adoracji, paramentach liturgicznych itp. ${ }^{37}$ Znamy jego liczne „kopie”, aż po masowo produkowane plakietki pielgrzymie, tanie obrazki czy wypieki z ciasta ${ }^{38}$. Zapewne takie praktyki sprzyjały transmedialności Weraikonów. Istniały przypadki wklejania niewielkich wizerunków Weraikonu, nierzadko przywiezionych z Rzymu znaków pielgrzymich, do modlite-

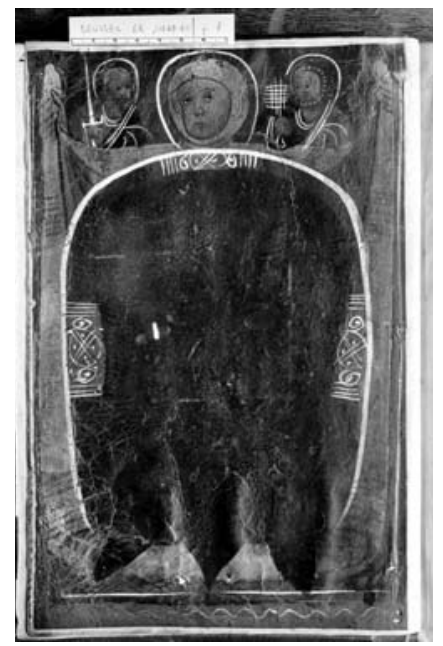

Il.7. Św. Weronika trzymająca chustę/relikwię - twarz Chrystusa wykonana na skórze, wklejona.

Godzinki księcia Jana de Berry. Bruxelles, Bibliothèque Royale Albert Ier, ms 11060-61, początek XV w., f. 8 .

(Źródło: https://veronicaroute.com/1410/01/08/xv-secolo-2-2/ (dostęp: 13.08.2019)).

Icon (Veronica) in the Verse Legend Veronica II: Medializing Salvation in the Late Middle Ages, „Seminar A: Journal of Germanic Studies”, 52 (2016) issue 2, s. 173-192.

${ }^{36}$ Bredekamp, Media, s. 213; J.F. Hamburger, Art and Female Spirituality in Late Medieval Germany, New York 1998, s. 332-333; A. Sand, Vision, Devotion, and Self-Representation in Late Medieval Art, Cambridge 2014, s. 57.

${ }^{37}$ Zob. teksty zawarte w: The Holy Face and the Paradox of Representation. Papers from a Colloquium hel dat the Bibliotheca Hertziana, Rome and the Villa Spelman, Florence, 1996, Hrsg. H.G. Kessler, G. Wolf, Bologna 1998 - tam też starsza literatura przedmiotu; M. Kapustka, Das berührte Bild? Eine unbekannte Vera Ikon-Tafel aus dem 15.Jahrhundert und die Fragen zur Funktion von Tuchdarstellungen, w: Grenzen überwindend. Festschrift für Adam S. Labuda zum 60.Geburtstag, Hrsg. K. Bernhardt, P. Piotrowski, Berlin 2006, s. 1-12; tenże, Figura i hostia. O obrazowym przywoływaniu obecności w późnym średniowieczu, Wrocław 2008, s. 232-234.

${ }^{38}$ Bredekamp, Media, s. 214; Hamburger, Art, s. 317-348. 
wników czy mszałów. Wklejone wizerunki Świętego Oblicza wykonane na skórze odnajdziemy np. w Godzinkach księcia de Berry (Bruksela, Bibliothèque Royale Albert ler, z ok. roku 1400-1410, Ms 11060-61, fol. 8r), w mszale pochodzącym z kościoła NMP w Gdańsku (Gdańsk, Biblioteka PAN, Ms.MarF.61, fol. 110v) ${ }^{39}$ czy późniejszy przykład modlitewnika (XVI/XVII wiek) z wklejonym Weraikonem, któremu towarzyszą symbole władzy papieskiej (Staatsbibliothek Berlin Preussischer Kulturbesitz, Mmgo191:fol. 10v ${ }^{40}$. Ciekawym przykładem tego rodzaju działań jest Weraikon z opactwa cysterskiego w Rostocku, namalowany na pergaminie, naklejony na deskę, następnie przesłonięty szybą i obramiony, służący dewocji ${ }^{41}$. Nawet $\mathrm{w}$ przypadku medialnie jednorodnych obrazów z motywem Weraikonu te ostatnie bywały przedstawiane tak, by zaznaczyć ich odrębny substancjalny status, jak np. w graduale cysterskim przechowywanym w Pelplinie (Biblioteka Seminarium Duchownego, MS L 13, fol. 17 r), gdzie wyobrażono chustę ze Świętym Obliczem jako rozpiętą na wyłaniających się zza bordiury obrazu dużych hakach ${ }^{42}$, czy licznych wizerunkach, gdzie twarz ukazywano jako niepoddającą się układowi chusty, pozostającą na niej jak „nałożona” (taki sposób przedstawiania był wręcz normą; zob. Weraikon we wspomnianym pelplińskim graduale, także na fol.92v. Właściwie trudno wskazać przykłady, które tej zasady nie respektowały).

Szerzenie się kultu Świętego Oblicza skutkowało nie tylko swoistą swobodą medialną, ale i ukazywaniem wizerunku w różnych kontekstach, a co za tym idzie, nadawaniem mu nowych znaczeń. Święte Oblicze zachowywało przy tym pewną niezależność/autonomię; wizerunek nadal pozostawał „cudownym” obrazem. Taki klimat zapewne sprzyjał powstawaniu i innych toruńskich malowideł o tej tematyce. Omawiany przykład w kościele pw. św. Jakuba należałby do najstarszych w mieście (z ok. 1350 roku pochodzi malowidło w domu przy ul. Żeglarskiej 17, a z ok. 1370 roku - nowo odkryte malowidło na zachodniej ścianie nawy środkowej korpusu kościoła pw. św. Jakuba) ${ }^{43}$. W naszym przypadku najwyraźniej chciano zaakcentować odrębność (i wyjątkowość) samego wizerunku Świętego Oblicza, zapewne z racji jego statusu obrazu „prawdziwego”

${ }^{39}$ Zob. Kapustka, Figura, s. 367 i przyp. 32, gdzie m.in. przykłady wklejania Weraikonów do średniowiecznych mszałów na Śląsku, w których funkcjonowały jako tzw. Paxbild; zob. też: Weitbrecht, The Vera Icon, s. 184 -186.

${ }^{40}$ Tamże, s. 186.

${ }^{41}$ Hamburger, Art, s. 332.

${ }^{42}$ Zob. G. Jurkowlaniec, Watki treściowe dekoracji pelplińskiego graduału L.13, „Biuletyn Historii Sztuki”, 60 (1998) nr 3-4, s. 354; Hamburger, Art, s. 342, 344

${ }^{43}$ Niezwykle interesujące okazało się odkrycie kolejnego (po zdjęciu pobiał w 2018 roku) monumentalnego średniowiecznego przedstawienia głowy Chrystusa w nimbie, znajdującego się wysoko na zachodniej ścianie nawy głównej, stanowiącego niejako pendant do wizerunku na ścianie prezbiterium. Malowidło to miało w okresie gotyku dwie redakcje. W zewnętrznej, lepiej zachowanej warstwie malarskiej, powtórzono zapewne wizerunek Chrystusa (pierwotny niezachowany; czytelny w rozmytym zarysie), który zyskał asystę dwóch aniołów. Nadano mu tym samym charakter Weraikonu. Mielibyśmy zatem w kościele świętojakubskim nie tylko przykład multiplikacji przedstawień Świętego Oblicza, ale i specyficzne, naprzeciwległe usytuowanie dwu wizerunków, co rodzi dalsze, godne uwagi, odniesienia semantyczne. 
i jego obrazowego kontekstu, w jakim go - w lokalnych warunkach - ukazano ${ }^{44}$. Odpowiadałoby to istotnej dla transmedialności wewnętrznej heterogeniczności obrazu, a jednocześnie tworzyłoby nową jakość medialną, przydając obrazowi tablicowemu (a jednocześnie kopii obrazu-relikwii) nowe, „stałe” miejsce ekspozycji, a wraz z nim wzbogacając jego semantykę i możliwości „działania”.

Jeśli przyjmiemy, iż faktycznie funkcjonował w kościele pw. św. Jakuba tego rodzaju obraz, to Weraikon ten należałby do takich obrazów, które „działały” raczej dzięki uświadamianiu sobie ich obecności, niż dzięki artystycznej klasie detali czy konwencji stylowej. Trudno dostępne wzrokowo usytuowanie tego malowidła - widzianego z dużej odległości, bardziej wyczuwanego dzięki kontekstowi niż rozpoznawanego, wpisuje je w sugestywną propozycję Didi-Hubermana, by docenić bagatelizowaną wcześniej rolę niektórych obrazów w średniowieczu obrazów, które nie były przeznaczone do detalicznej wzrokowej penetracji przez widza/wiernego (czyli „do czytania”). Są one bowiem obrazami, których zadaniem jest nie tyle przedstawiać, co uobecniać (widzialność versus wizualność) i jako takie działają jak symptom: nieuchwytne, niedookreślone, „patrzące” na widza z całą mocą swego spojrzenia ${ }^{45}$; wizerunek jest wzrokowo dostępny, ale nie jako przedstawienie. W tej niedostępności szczegółów przedstawienia uwydatnia się rola medium ${ }^{46}$. Jako taki prezentowany był przez anioły, pojmowany jako przyniesiony przez nich znak zbawienia, zgodnie z tekstem psalmu „okaż nam oblicze swoje a będziemy zbawieni" (Ps 79,20).

Toruńskie malowidło powstało w okresie, gdy kult rzymskiego Weraikonu znacząco wzrósł ${ }^{47}$; w XIV wieku wystawiano go kilkakrotnie w ciągu roku, obnoszono w procesjach, wydłużano wystawiane na niego odpusty itd. ${ }^{48}$ Rok 1350 , obchodzony w Rzymie jako rok jubileuszowy, zgromadził w Świętym Mieście

${ }^{44}$ Zob. A.S. Labuda, Wrocławski oltarz św. Barbary i jego twórcy. Studium o malarstwie ślaskim połowy XV wieku, Poznań 1984, s. 170 - w odniesieniu do późnogotyckiego obrazu Weraikonu $\mathrm{z}$ kościoła NMP w Legnicy.

${ }^{45}$ G. Didi-Huberman, Przed obrazem. Pytanie o cele historii sztuki, Gdańsk 2011, s. 126-135. Didi-Huberman używał przy tym znamiennego określenia: obraz-symptom - s. 119, 135.

${ }^{46}$ Zgodnie z przekonaniem Beltinga, że medium to nie tylko materiał-tworzywo, ale i forma obrazu: H. Belting, Obraz i jego media. Próba antropologiczna, „Artium Quaestiones”, 9 (2000) s. 295-322, gł. s. 297 zob. także: Bredekamp, Media, s. 211-212, gdzie zestawienie poglądów na temat medium m.in. McLuhana i Luhmanna wraz z nową propozycją Bredekampa.

${ }^{47}$ Kult rozszerzał się począwszy od końca XII wieku, gdy wzniesiono dlań specjalne cyborium, i początku XIII wieku, kiedy decyzją papieża Innocentego III ustanowiono procesję, w trakcie której św. Oblicze w specjalnie sporządzonym do tego relikwiarzu było niesione z bazyliki św. Piotra do szpitala San Spirito. Por. A. van Dijk, The Veronica, the Vultus Christi and the veneration of icons in medieval Rome, w: Old Saint Peter's, Rome, eds. R. McKitterick, J. Osborne, C. Richardson, Cambridge 2013, s. 229-256.; O. Kwapis, Do Rzymu! Sztuka i wielkie jubileusze (1300-1575), Warszawa 2014, s. 310-311; Sand, Vision, s. 30. O dziejach rzymskiego Weraikonu i miejscach jego eksponowania por. G. Wolf, „Pinta della nostra effige”. La Veronica come richiamo dei Romei e Giubilei. Il pellegrinagio medievale a San Pietro (350-1350), Milano 1999, s. 211-218.

${ }^{48}$ Szczególne zasługi położyli papieże: Jan XXII (1316-1334), m.in. autor hymnu na cześć Świętego Oblicza, czy nieco później, w latach 60. XIV wieku - Urban V. Zob. E. von Dobschütz, Chritusbilder. Untersuchungen zur christlichen Legende, Leipzig 1899, s. 224-226. 
licznych obcych przybyszów, w tym wielu z krajów niemieckich ${ }^{49}$. Być może umieszczono na ścianie wschodniej prezbiterium kościoła pw. św. Jakuba jedną z licznych kopii, jakie wówczas przywożono z Rzymu (lub może ktoś otrzymał w darze taką kopię?). Malowana architektoniczna obudowa mogłaby być w tym przypadku obrazowym odpowiednikiem cyborium, jakie w rzymskiej bazylice pw. św. Piotra nakazał wznieść papież Celestyn III w roku 1193 dla prezentacji Świętego Oblicza; czyli ,prawdziwość” toruńskiego obrazu wzmacniałoby obrazowe przywołanie realnego kontekstu rzymskiej relikwii ${ }^{50}$. Wiemy, że cesarz Karol IV przywiózł z Rzymu, może w roku 1355 lub w latach 1368-1369, Weraikon do katedry praskiej ${ }^{51}$. To mógł być dla społeczności środkowoeuropejskich inspirujący przykład ${ }^{52}$. Byłoby to prawdopodobne także $\mathrm{z}$ tego względu, że nie znamy żadnych przekazów źródłowych mówiących o obecności w przestrzeni miejskiej średniowiecznego Torunia, czy też w konwencie krzyżackim lub u cysterek (w 1345 roku wielki mistrz Ludolf von König potwierdził ich prawo patronatu nad kościołem) jakiegoś szacownego, lokalnego obrazu Świętego Oblicza. Gdyby przyjąć, że w toruńskim malowidle ściennym wykorzystano obraz wykonany na innym nośniku, nie należałoby więc traktować tego jako aktu poczynionego względem jakiegoś czczonego lokalnego wizerunku, bliskiego późniejszemu artystycznemu „oprawianiu” dawnych średniowiecznych wyobrażeń ${ }^{53}$.

Obraz włączony do sceny, zachowujący odrębność medialną (jako coś przyniesionego, przywiezionego, ale i szczególnego, substancjalnie odrębnego), wpisuje się także w rosnący kult eucharystyczny ${ }^{54}$. Lokalizacja przedstawienia na

${ }^{49}$ J. Sumption, Pilgrimage. An Image of Mediaeval Religion, London 1975, s. 238; zob. także: Kwapis, Do Rzymu, s. 69-70.

${ }^{50}$ Tamże, s. 310.

${ }^{51}$ Zob. J. Kuthan, J. Royt, Karel IV, Císařa česky král - vízíonár̆ a zakladatel, Praha 2016, s. 622. W kręgu jego naśladownictw wymienia się Weraikon pochodzący z kościoła św. Marii Magdaleny we Wrocławiu, ok. 1400. Zob. H. Braune, E. Wiese, Schlesische Malerei und Plastik des Mittelalters: kritischer Katalog der Ausstellung in Breslau 1926, Leipzig 1929, s. 169.

${ }^{52}$ Warto nadmienić, że kościół św. Jakuba leżał na trasie pielgrzymek. Zob. literatura dotycząca zagadnienia pielgrzymek: A. Mańkowski, Pielgrzymki Pomorzan w wiekach średnich, „Miesięcznik Diecezji Chełmińskiej”, 79 (1936) s. 247-258; Drogi św. Jakuba na obszarze krajów południowego wybrzeża Bałtyku, red. W. Rozynkowski, A. Zajączkowska, Lębork 2010; H. Manikowska, Jerozolima, Rzym, Compostela. Wielkie pielgrzymowanie u schytku średniowiecza, Wrocław 2008; R. Knapiński, Kult św. Jakuba Większego Apostoła w Europie Środkowo-Wschodniej, Lublin 2002.

${ }^{53} \mathrm{Względem} \mathrm{tych} \mathrm{zjawisk} \mathrm{analizowany} \mathrm{przykład} \mathrm{wykazuje} \mathrm{jednako} \mathrm{pewne} \mathrm{podobieństwo.} \mathrm{Zob.}$ szereg różnorakich przykładów omówionych u: G. Jurkowlaniec, Epoka nowożytna wobec średniowiecza. Pamiątki przeszłości, cudowne wizerunki, dzieła sztuki, Wrocław 2008. Tam także literatura do tej problematyki. Obecnie w samym kościele św. Jakuba mamy kilka takich zespoleń: XIV-wieczną figurę Marii z Dzieciątkiem na masce lunarnej - w rokokowej oprawie z wyobrażeniami aniołów, XIV-wieczny krucyfiks - Drzewo Życia - otoczony nowożytnymi rzeźbami Marii i św. Jana czy włączona w nowożytną strukturę ołtarzową późnogotycka rzeźba Marii z Dzieciątkiem, Zw. Różańcową.

${ }^{54}$ Od XIII wieku obrazy Weraikonu prezentowano jako swoisty odpowiednik elevatio hostiae. Zob. Kapustka, Figura, s. 232. Wynikało to z przekonania/wiary w odpowiedniość: Chrystus sam jako osoba - był przez św. Pawła określany jako jedyny pośrednik-mediator między Bogiem a ludź- 
ścianie wschodniej nad/za ołtarzem głównym, w centrum sprawowania liturgii eucharystycznej, pozwala traktować domniemany Weraikon jako obrazowy odpowiednik dogmatu o realnej obecności Chrystusa w postaciach eucharystycznych. Wspomniane wyżej malowidło ścienne w domu przy ul. Żeglarskiej w Toruniu (ok. 1350 rok) poświadcza, iż takie eucharystyczne odniesienie dla Weraikonu znane było lokalnej społeczności. Święte Oblicze ukazano tu bowiem pomiędzy wizerunkami św. Jana Ewangelisty trzymającego kielich z hostią i św. Jana Chrzciciela zapewne ze znakiem Baranka Bożego jako atrybutem ${ }^{55}$. Alexa Sand analizując różnorakie eucharystyczne konotacje Weraikonu, wskazuje także starsze, jak i współczesne toruńskim przykłady takich właśnie skojarzeń, szczególnie w obrębie malarstwa książkowego. Przedstawienia Weraikonów w modlitewnikach i psałterzach - zarówno ze względu na formę, jak i przede wszystkim poprzez towarzyszące im teksty - słusznie uznaje za wizualne aluzje do Hostii ${ }^{56}$. Twarz Chrystusa na chuście traktowano także jako odpowiednik hostii na korporale ${ }^{57}$ : „twarz była hostią, hostia była twarzą" ${ }^{58}$. Przyjmując, iż wśród ówczesnych takie skojarzenia (czy wręcz wymienność!) były dopuszczalne, można mniemać, że na pomysł włączenia w malowidło na ścianie prezbiterium medialnie odrębnego wizerunku Weraikonu mogło mieć wpływ takie rozumowanie. Weraikon toruński łączy bowiem w sobie „mobilność” i jednocześnie substancjalną odrębność, podobnie jak hostie ${ }^{59}$.

W tym kontekście warto wrócić do wspomnianych na początku niniejszego artykułu wyobrażeń aniołów na sklepieniu prezbiterium i towarzyszącej im inskrypcji (zob il. 2, 8). Lokalizacja tych wyobrażeń wprost nad ołtarzem głównym kościoła wraz z ową inskrypcją, którą należy traktować jako zapis „głosu” tychże aniołów, to obraz celebry mszalnej, konkretnie - początku Kanonu mszalnego. Starotestamentowy tekst Sanctus włączony do liturgii Mszy św. jako aklamacja odnosi się już nie tylko do mocy Najwyższego, ale i Jego Syna, przychodzącego

mi, a przez Mikołaja z Kuzy jako „medium absolutum”. Zob. Ch. Kiening, Einleitung, w: Medialität des Heils, s. 8, 10-11

${ }^{55} \mathrm{Na}$ eucharystyczne odniesienia Weraikonu w tym malowidle zwrócił uwagę J.F. Hamburger: Ars, s. 333. Stan zachowania wizerunku św. Jana Chrzciciela niestety, nie pozwolił stwierdzić, co faktycznie święty trzymał w dłoni(ach), tak więc znak Baranka Bożego jest tu jedynie domniemaniem.

${ }^{56}$ M.in. w tak znanych, jak: Bonmont Psalter, ok. 1260, Modlitewnik Yolande de Soissons, Godzinki z Châlons-sur-Marne, 1 ćw. XIV w. Zob. Sand, Vision, s. 55.

${ }^{57}$ Belting, Obraz i kult, s. 612.

${ }^{58}$ Literatura na ten temat jest obszerna, zob. np. Labuda, Wrocławski oltarz, s. 172; Hamburger, Ars, s. 345 - „Images of the Veronica may have substituted for the Host, supplying a surrogate sacramental presence"; G.Wolf, From Mandylion to Veronica. Picturing the Disembodied Face and Disseminanting the True Image of Christ in the Latin West, w: The Holy Face and the Paradox of Representation. Papers from a Colloquium held at the Bibliotheca Hertziana, Rome and the Villa Spelman, Florence 1996, ed. H.G.Kessler, G. Wolff, Bologna 1998 (Villa Spelman Colloquia, vol. 6), s. 172; Ch. Egger, Papst Innozenz III. und die Veronica. Geschichte, Theologie, Liturgie und Seelsorge, tamże, passim.

${ }^{59}$ Sand, Vision, s. 55. 
w Jego imieniu - Wiecznego Kapłana ${ }^{60}$. Tak więc aklamacja ta głosi chwałę Bożą realizującą się w Eucharystii ${ }^{61}$. Gdyby przyjąć niegdysiejszą obecność Weraikonu w polu obrazu na ścianie wschodniej prezbiterium, mielibyśmy do czynienia ze swoistą eucharystyczną ,triadą": zawarta w obrazie aniołów eucharystyczna wymowa konkretnego momentu Mszy anielskiej, sprawowana realnie Eucharystia przez kapłana (łącząca się z chórem anielskim na sklepieniu) i obraz - odpowiednik hostii adorowany przez wyobrażone anioły.

Mimo że obecność w toruńskim kościele pw. św. Jakuba tablicowego obrazu Weraikonu jako elementu większej struktury obrazowej może być jedynie domniemaniem, to kilka faktów jak: pozostawienie małej, czworobocznej powierzchni ściany bez tynku, położenie na niej cienkiej czerwonej warstwy malarskiej, istnienie zagadkowej „odsadzki”, wielka podówczas popularność wizerunku Swiętego Oblicza, jak i spójność całego programu obrazowego, pozwala przyjąć taki wariant jako najbardziej prawdopodobny. Dlatego uzgodniliśmy z firmą przeprowadzającą konserwację prezbiterium, by po ukończeniu prac konserwatorskich, w 2018 roku, umieszczona została w polu pod baldachimem współczesna, quasi-replika Świętego Oblicza.

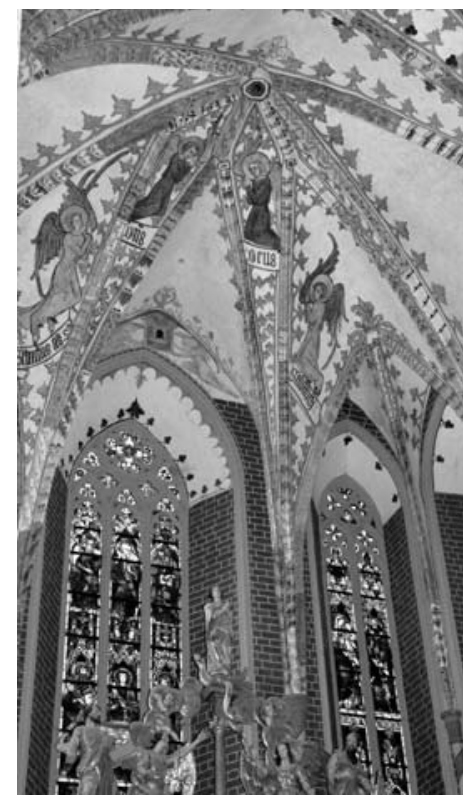

I1.8. Widok na wschodnią ścianę prezbiterium kościoła św. Jakuba w Toruniu po wstawieniu w pole malowidła współczesnej „repliki” Weraikonu.

(Fot. Anna Błażejewska)

${ }^{60}$ M.B. McNamee, Vested Angels: Eucharistic Allusions in Early Netherlandish Paintings, Leuven 1998, s. 101.

${ }^{61}$ B. Nadolski, ks., Liturgika, t. 4: Eucharystia, Poznań 1992, s. 188. O eucharystycznych konotacjach aklamacji Sanctus - zob. u: McNamee, Vested Angels, s. 152-153 - gdzie przywołuje wczesnoniderlandzkie obrazy z przedstawieniami celebry mszalnej aniołów, na których szatach znajdują się analogiczne inskrypcje. 


\section{BIBLIOGRAFIA}

\section{Źródła}

Dokumentacja z prac konserwatorskich 1956-59: kościół św. Jakuba - konserwacja malowideł ściennych 1956-59, mps, Toruń 1959, Archiwum Kujawsko-Pomorskiego Urzędu Ochrony Zabytków Toruń, sygn. 205.

Dokumentacja prac konserwatorsko-restauratorskich wnętrza prezbiterium i zakrystii kościoła św. Jakuba Apostoła w Toruniu - I etap, oprac. Irena i Jan Bulderberg, Włodzimierz Rumiński Relief s.c., Toruń 2014, kpis, Archiwum Miejskiego Konserwatora Zabytków w Toruniu, sygn. 6679.

Dokumentacja prac konserwatorsko-restauratorskich wnętrza prezbiterium i zakrystii kościoła św. Jakuba Apostoła w Toruniu - II i III etap, oraz prac konserwatorsko - restauratorskich ścian i łuku tęczowego, oprac. Irena i Jan Bulderberg, Włodzimierz Rumiński Relief s.c., Toruń 2016, kpis, Archiwum Miejskiego Konserwatora Zabytków w Toruniu, sygn.7000.

\section{Opracowania}

Belting Hans, Obraz i jego media. Próba antropologiczna, „Artium Quaestiones”, 9 (2000) s. 295-322.

Belting Hans, Obraz i kult. Historia obrazu przed epoka sztuki, Gdańsk 2010.

Biblia - to jest Księgi Starego i Nowego Testamentu, przełożone przez ks. J. Wujka (przedruk), Warszawa 1950.

Braune Heinz, Wiese Erich, Schlesische Malerei und Plastik des Mittelalters: kritischer Katalog der Ausstellung in Breslau 1926, Leipzig 1929.

Bredekamp Horst, Media obrazowe, „Artium Quaestiones”, 15 (2004) s. 209-231.

Brutzer Gregor, Mittelalterliche Malerei im Ordenslande Preussen, Teil I: Westpreussen, Danzig 1936.

Cenne odkrycia $w$ presbiterjum kościoła św. Jakóba $w$ Toruniu, „Słowo Pomorskie”, nr 267 (19 XI 1933), s. 12.

Chmarzyński Gwido, Sztuka pomorska w: Słownik Geograficzny Państwa Polskiego i Ziem historycznie z Polska zwiazanych, red. S. Arnold, t. 1, z. 4: Pomorze Polskie, Pomorze Zachodnie, Prusy Wschodnie, Warszawa 1937, szp. 353-399.

Dalbor Witold, Średniowieczne malowidła $w$ kościele św. Jakuba w Toruniu, „Teka Pomorska”, R. 1-2 (1936-37) nr 3-4, s. 8-11.

Didi-Huberman Georges, Przed obrazem. Pytanie o cele historii sztuki, Gdańsk 2011.

Dijk Ann van, The Veronica, the Vultus Christi and the veneration of icons in medieval Rome, w: Old Saint Peter 's, Rome, eds. R. McKitterick, J. Osborne, C. Richardson, Cambridge 2013, s. 229-256 (dostęp: 10.08.2019).

Dobschütz Ernst von, Chritusbilder. Untersuchungen zur christlichen Legende, Leipzig 1899.

Domasłowski Jerzy, Polska pótnocno-wschodnia, w: Materiały do katalogu gotyckich malowidet ściennych $w$ Polsce, t. 3, red. A. Karłowska-Kamzowa, Poznań 1981, s. 41-62.

Domasłowski Jerzy, Kościót parafialny Nowego Miasta p.w. św. Jakuba, w: Malarstwo gotyckie w Polsce, t. 2: Katalog zabytków, red. A.S. Labuda, K. Secomska, Warszawa 2004, s. 101-102.

Egger Christoph, Papst Innozenz III. und die Veronica. Geschichte, Theologie, Liturgie und Seelsorge, w: The Holy Face and the Paradox of Representation. Papers from a Colloquium held at the Bibliotheca Hertziana, Rome and the Villa Spelman, Flo- 
rence 1996, ed. H.G. Kessler, G. Wolff, Bologna 1998 (Villa Spelman Colloquia, vol. 6), s. 181- 203.

Hamburger Jeffrey F., Art and Female Spirituality in Late Medieval Germany, New York 1998.

Jurkowlaniec Grażyna, Epoka nowożytna wobec średniowiecza. Pamiątki przeszłości, cudowne wizerunki, dzieła sztuki, Wrocław 2008.

Jurkowlaniec Grażyna, Wątki treściowe dekoracji pelplińskiego graduału L.13, „Biuletyn Historii Sztuki”, 60 (1998) nr 3-4, s. 353-380.

Kapustka Mateusz, Das berührte Bild? Eine unbekannte Vera Ikon-Tafel aus dem 15.Jahrhundert und die Fragen zur Funktion von Tuchdarstellungen, w: Grenzen überwindend. Festschrift für Adam S. Labuda zum 60.Geburtstag, Hrsg. K. Bernhardt, P. Piotrowski, Berlin 2006, s. 1-12.

Kapustka Mateusz, Figura i hostia. O obrazowym przywoływaniu obecności w późnym średniowieczu, Wrocław 2008.

Kessler Herbert L., Wolf Gerhard (eds.), The Holy Face and the Paradox of Representation. Papers from a Colloquium hel dat the Bibliotheca Hertziana, Rome and the Villa Spelman, Florence 1996, Bologna 1998.

Kiening Christian, Einleitung, w: Medialität des Heils im späten Mittelalter, Hrsg. C. Dauven-van Knippenberg u.a., Zürich 2009, s. 7-20.

Kluszczyński Ryszard W. (red.), Transmedializm. O twórczości Ryszarda Waśki, w: Obrazy na wolności. Studia z historii sztuk medialnych w Polsce, Warszawa 1998, s. 87-97.

Knapiński Ryszard (red.), Kult św. Jakuba Większego Apostoła w Europie Środkowo-Wschodniej, Lublin 2002.

Knothe Zygmunt, Kościót św. Jakuba, w: Kościót i parafia świętego Jakuba w Toruniu. Z okazji 25-letniego jubileuszu kapłaństwa Ks. L. Kozłowskiego, dodatek do: „Wiadomości Kościelne”, Toruń 1938, s. 19-33.

Konieczny Aleksander, Dzieje budowy kościoła św. Jakuba w Toruniu $w$ XIV wieku w świetle analizy architektonicznej, „Biuletyn Historii Sztuki”, 74 (2012) nr 1, s. 5-32.

Krantz-Domasłowska Liliana, Domasłowski Jerzy, Wyposażenie wnętrz, w: Kościót św. Jakuba w Toruniu, seria: „Zabytki Polski Północnej”, nr 11, Torun 2001, s. 72.

Kuthan J Jiří, Royt Jan, Karel IV, Císařa česky král - vízionář a zakladatel, Praha 2016.

Kwapis Olaf, Do Rzymu! Sztuka i wielkie jubileusze (1300-1575), Warszawa 2014.

Labuda Adam S., Wrocławski ottarz św. Barbary i jego twórcy. Studium o malarstwie ślaskim połowy XV wieku, Poznań 1984.

Lexikon der christlichen Ikonographie, Hrsg. E. Kirschbaum u.a., Allgemeine Ikonographie, Bd 1, Rom 1968, h. Bundeslade, Sp. 341-343.

Malowidła ścienne w kościele św. Jakuba w Toruniu, dokumentacja historyczna, oprac. M. Michnowska, mpis, Toruń 1962, Archiwum Kujawsko-Pomorskiego Urzędu Ochrony Zabytków w Toruniu, sygn. 208.

McNamee Maurice B., Vested Angels: Eucharistic Allusions in Early Netherlandish Paintings, Leuven 1998

Manikowska Halina, Jerozolima, Rzym, Compostela. Wielkie pielgrzymowanie u schytku średniowiecza, Wrocław 2008.

Mańkowski Alfons, Pielgrzymki Pomorzan w wiekach średnich, „Miesięcznik Diecezji Chełmińskiej", 79 (1936) s. 247-258.

Michnowska Maria, Malowidła ścienne z XIV w. w kościele św. Jakuba w Toruniu, „Teka Komisji Historii Sztuki” 3, Prace Wydziału Filologiczno-Filozoficznego, Towarzystwo Naukowe w Toruniu, t. 15, red. J. Puciata-Pawłowska, Torun 1965, s. 5-71.

Mozgoł Andrzej, ks., Teologia Arki Przymierza w Ps 132, Jr 3, 14-18 oraz 2 Mch 2, 1-8, „Śląskie Studia Historyczno-Teologiczne”, 33 (2000) s. 127-158. 
Nadolski Bogusław, Liturgika, t. 4: Eucharystia, Poznań 1992

Nowiński Janusz, Ars eucharistica. Idee, miejsca i formy towarzyszace przechowywaniu eucharystii w sztuce wczesnochrześcijańskiej i średniowiecznej, Warszawa 2000.

Odkrycie średniowiecznych malowidet ściennych w kościele św. Jakóba, „Słowo Pomorskie", nr 12 (15 I 1935), s. 6.

Odsłonięto cenny zabytek średniowiecza, „Słowo Pomorskie”, nr 208 (8 IX 1936), s. 8.

Pismo Święte Starego i Nowego Testamentu, Poznań 1980.

Rozynkowski Waldemar, Zajączkowska Alicja (red.), Drogi św. Jakuba na obszarze krajów potudniowego wybrzeża Battyku, Lębork 2010.

Rubiś Wojciech, Zagadnienia transmedialności w sztuce współczesnej. Wokót książki: Sztuki $w$ przestrzeni transmedialnej pod redakcja Tomasza Załuskiego, „Estetyka i Krytyka", 35 (2014) nr 4, s. 219-228.

Sand Alexa, Vision, Devotion, and Self-Representation in Late Medieval Art, Cambridge 2014

Schlie Heike, Vera Ikon in Medienverbund. Die Wirksamkeit der Sakramente und der Wirkung der Bilder, w: Medialität des Heils im späten Mittelalter, Hrsg. C. Dauven-van Knippenberg u.a., Zürich 2009, s. 61-82.

Sumption Johnatan, Pilgrimage. An Image of Mediaeval Religion, London 1975.

Turska Hailna, Veraicon $w$ średniowiecznym Toruniu, ,Acta Universitatis Nicolai Copernici”, seria: „Zabytkoznawstwo i Konserwatorstwo”, 44 (2013) s. 57-67.

Weitbret Julia, The Vera Icon (Veronica) in the Verse Legend Veronica II: Medializing Salvation in the Late Middle Ages, ,Seminar A: Journal of Germanic Studies”, 52 (2016) issue 2, s. 173-192.

Wojtyniak-Dębińska Ewa, Transmedialność w grafice współczesnej, w: Sztuki w przestrzeni transmedialnej, red. T. Załuski, Łódź 2010, s. 173-179.

Wolf Gerhard, From Mandylion to Veronica. Picturing the Disembodied Face and Disseminanting the True Image of Christ in the Latin West, w: The Holy Face and the Paradox of Representation. Papers from a Colloquium held at the Bibliotheca Hertziana, Rome and the Villa Spelman, Florence 1996, ed. Kessler H.G., Wolff G, Bologna 1998 (Villa Spelman Colloquia, vol. 6), s. 153-179

Wolf Gerhard, „Pinta della nostra effige”. La Veronica come richiamo dei Romei e Giubilei. Il pellegrinagio medievale a San Pietro (350-1350), Milano 1999.

Załuski Tomasz (red.), Transmedialność?, w: Sztuki w przestrzeni transmedialnej, Łódź 2010, s. 9-18.

Żankowski Ryszard, Gotyckie malowidła ścienne w kościele św. Jakuba w Toruniu, odkryte $i$ odrestaurowane w potowie XX wieku. Uwagi konserwatora o ich historii i ponownej, niedawnej konserwacji, w: Dzieje skarby kościoła świetojakubskiego w Toruniu. Materiaty IV Sesji Naukowej SHS O/Toruń, red. K. Kluczwajd, seria: „Dzieje i skarby kościołów toruńskich", Toruń 2010, s. 175-212.

\section{Netografia}

Neuß Wilhelm, Bundeslade, w: "Reallexikon zur Deutschen Kunstgeschichte", 3 (1950) Sp. 112-118; w: RDK Labor, http://www.rdklabor.de/w/?oldid=89394. 


\title{
MEDIEVAL WALL PAINTING ON THE EASTERN WALL OF THE PRESBYTERY OF ST JAMES CHURCH IN TORUŃ. A TRANSMEDIA IMAGE CULTURE?
}

\begin{abstract}
Summary
Recent conservation works in the presbytery of St James's Church in Torun revealed several details of a previously poorly readable painting from the third quarter of the 14th century. These details shed interesting light on its iconography and on the complex media character. Upon close observation of a freshly cleaned representation of angels adoring (and supporting) the hitherto difficult to define quadrilateral shape crowned with a small gable, high on the eastern wall of the presbytery, identified by default as Veraicon, it turned out that there was most probably a small panel painting inserted into the quadrilateral field. This is evidenced by: a few centimetres long 'gooseneck' made with plaster - located in the lower part of the canopy-shaped architectural framing, finished with a black contour, no traces of plaster (only an unusual, thin layer of red polychrome staining within the framing). Due to the fact that this alleged painting has not survived, the assumption that it depicted Veraicon, captured by an architectural ciborium, perhaps imitating the Roman way of presenting the cloth relic, is based on the popularity of representations of this iconographic type, located in the context of the altar and on the base of the existing painting context (the immediate vicinity on the vaulting also includes images of adoring angels with the tersanctus inscription). Considering the great popularity of this type of representation in the late Middle Ages, not only in monumental painting, the Torun example seems exceptional because of its transmediality: the whole is heterogeneous; a copy of the painting-relic appears in a new context and role, also changing the character of the painting. The source of such a concept was probably the extraordinary diversity (including media diversity) of the created copies of the Roman image. A similarity to this type of complex pictorial structure, in terms of media, can be found in illuminated manuscripts to which the images of the Holy Face made on leather, sometimes brought from Rome, were pasted. The Torun image could also have been of Roman origin; 14th century was a period of significant intensification of the cult of the Holy Face in Rome itself and beyond, if only thanks to numerous pilgrimages.

It should be noted that the functioning of the Veraicon, here painted on wood, is only a hypothesis, although we consider it highly probable. There is also another, less probable possibility that the mentioned gooseneck/shelf was created without any connection with the painting. In that case, it would be possible that the object of adoration was the Ark of the Covenant placed under the canopy or only a place 'waiting for' the Ark to appear in the 'temple of God' on the day of Judgement (Revelation 11:19).
\end{abstract}

Keywords: Church of St James; Veraicon; Holy Face; Toruń; Middle Ages

Translated by Marek Robak-Sobolewski 